\title{
The Challenges Facing Bottom up Planning Process in Korogwe Town Council in Tanzania
}

\author{
Mwakasangula Eliza \\ School of Public Administration and Management (SOPAM) \\ P.O.Box 2, Mzumbe University, Tanzania \\ E-mail: efaty@mzumbe.ac.tz \\ Tefurukwa, W. Oscar (Corresponding Author) \\ School of Public Administration and Management (SOPAM) \\ P.O.Box 2, Mzumbe University, Tanzania \\ E-mail: oscartefurukwa@gmail.com
}

Received: Feb. 9, 2018 Accepted: Mar. 8, 2018 Online published: Mar. 18, 2018

doi:10.5296/jpag.v8i1.12627 URL: https://doi.org/10.5296/jpag.v8i1.12627

\begin{abstract}
This paper focuses on the main challenges facing participation in the bottom up planning processes at Korogwe Town Council (KTC). The study used 329 respondents and employed interviews, informal discussion, observation, and documentary reviews to gather data. Mainly narration and content analyses were used to scrutinize all data.The findings show that there were: inadequate community participation in planning at KTC due to lack of motivation and training, shortage of staff, lack of funds, inflexibility, irresponsibility, and lack of council mechanism for participation. Consequently, there was low level of community members participating in bottom up planning process. In order to encourage more people to be part of planning process, among other things, there is need to improve (or introduce) motivation to and training of community members, leaders and officers for effective bottom up participation participate.
\end{abstract}

Keywords: participation challenges, planning process, bottom up planning, town council, Tanzania 


\section{Introduction}

The government of Tanzania has been passionate to re-introduce participation ${ }^{1}$ of local communities as another attempt to mobilize local resources towards improving development at the grass-root level (REPOA, 2008). Bottom up approach allows the local community members and other players to articulate their views which facilitate in delineating the development course for their area in accordance with development Vision 2025 in Tanzania (Baker et al.,2002). The process aims at creating awareness for both government officials and citizenry on the role of community participation in local community needs through bottom up planning process (Mollel, 2010). The Tanzanian government in 1998, adopted the Policy Paper on Local Government Reform which also emphases the bottom-up planning process $\left(\mathrm{URT}^{2}\right.$, 1998). It was another attempt designed to enhance good governance whereby planning system is supposedly to start from the bottom up, in particular, at the hamlet, village, to Ward Development Committee (including village representatives). This could promote and encourage people to have a sense of ownership in facilitating planning and projects implementation (Baker et al., 2002; REPOA, 2008). In addition, the Tanzania Development Vision 2025 underlines the commitment and the need for democratic participation at all levels in the development processes. For instance, section 5 (ii) (iii) explicitly stipulates that the vision could be attained if it 'permits a greater role for local actors to own and drive the process of their development. Local people know their problems best and are better placed to judge what they need, what is possible to achieve and how it can effectively be achieved' (URT, 1999).

There are various laws which underline the importance of participatory planning in Tanzania. They include Local Government Act No. 7 of 1982 (URT, 1982a), the Local Government Financial (Block Grants) Act (paragraph 5) (URT, 1982b). Act No. 7 of 1982 articulates the powers, responsibilities, and the functions of the various levels of LGAs in service delivery (URT, 1982a). These acts, inter alia empower the local communities to participate in planning, and demand the available government institutions to enable people to formulate their plans and targets (Baker,et al.,2002). While the government has indicated the will to give power the local community to take part in decision making, the process leaves much to desire.

There are still administrative practices which show that the district and council planners are rather dominant in the decision-making on what the local authorities should do (REPOA, 2008). The local government authorities in many occasions lacked autonomous to make decisions to meet the needs and wants of the local communities (Mollel, 2010, Ringo, et al., 2013). This can be articulated in several ways, for instance, through planning and grant allocations. Financially, in 2007 over 90\% local government authorities depended on the

\footnotetext{
${ }^{1}$ Public participation is one of the principles of good governance, other are principles of good governance: democratic elections, rule of law, equity, accountability, integrity and transparency (REPOA, 2008).

${ }^{2}$ Stands for the United Republic of Tanzania
} 
central government (REPOA, 2008). Worse still, the central government grant to local governments is the package accompanied with conditions (Fjeldstad, 2010). In most cases such directives could not provide a room for local community to making decisions (Mollel, 2010). This was a top down approach. It did not involve the local communities in Tanzania because the central government continued to dictate the development activities and denied the local citizenry to identify their most priorities for implementation. It also contradicts the ambitions of the government to achieve its Vision 2025 through empowering the local communities (Mallya, 2015). Hence, the need to investigate the dilemma facing planning processes in facilitating participation of the local community members at the Mtaa, Ward, and Council levels in Tanzania. In particular, the paper examined the challenges facing the bottom up planning process in Korogwe Town Council (KTC) and proposed the remedies.

The rest part of this study is organised as follows: section two is the conceptual framework, section three is literature review and section four presents research methods employed in this study. We present and discuss challenges the KTC encountered in section five. In section six we propose remedies for the challenges. The summary and recommendation are in section seven.

\section{Conceptual Framework}

The participation of the people on issues that affect their daily activities matters. This can be effective only if there are skilled, dedicated, and committed bureaucrats; change in performance behaviours; steady and sufficient flow of revenues; effective council policy and regulations; and creativity amongst stakeholders. All this would result in improving people participation grounded at the grassroots.

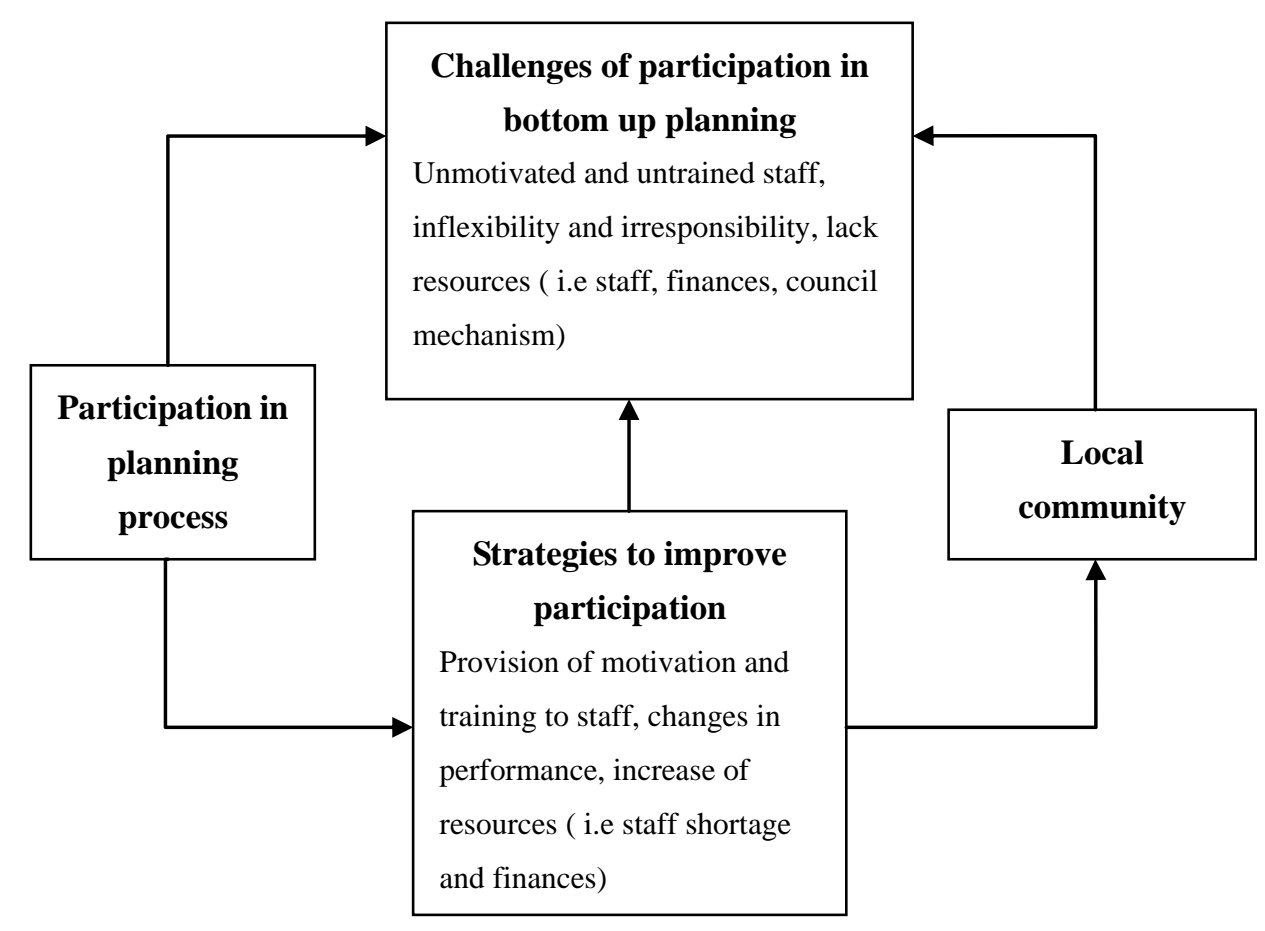

Figure 1. Conceptual Framework for Community Participation 
Source: Authors, 2018

\section{Community Participation in Development Programmes}

Colonial masters considered community development and participation programmes as an approach to boost local welfare, and training people in the areas of administration (Mayo, 1994). The colonial masters viewed such programmes as a way of promoting better the entire community and through which local members could actively participate on the initiative of the community (ibid). However, early community development programmes have been condemned on the ground that though they had elements of community participation and bottom-up considerations, still they remained paternalistic. Their main focus was getting backward people in the right frame of mind that was associated with unpaid voluntary labour for colonial development schemes (Manghezi, 1976). Alternatively, the most preferred term is community participation. Currently, the concept is among the models of the initiatives of the grassroots community development (Ali, 2013). Participation refers to the process through which the stakeholders influence and share control over development initiatives, and the decisions and resources which affects them (World Bank, 2004a). This implies that the community is capable of introducing and executing development activities in pursuing vision of the local authorities. The degree of community participation of the local citizens may include, "contribution of labour, consultation, cash, items, and behavioural changes, involvement in administration, management, and decision making" (Ali, 2013:7). As the process enables the citizens to respond to the public issues, and take part in decisions that in turn affect their life. Community participation is one of the ways of attracting projects and programmes and solving some problems (Lipka, et al., 1985).

\subsection{Challenges of Participation in Bottom up Planning Process}

Local community participation helps to improve the quality of decision making and policy formulation by tapping into more extensive and alternative sources of information and viewpoints (i.e. hidden knowledge) (World Bank, 2004b). This also may help to bridge diverse interests. It is one of the elements of the good governance (Khwaja, 2004). Incorporation of the community's ideas in planning may ensure fulfilling the expectations of the citizens' priorities (Michels and De Graaf, 2010). Transparency and accountability increase as the citizenry at the lower level scrutinise their authorities. Consequently, local community participation sustains the legitimacy of the decisions reached (Kampen, 2009).

Urban authorities like any other local authorities, are responsible for the social welfare and economic well-being of all persons within their area of jurisdiction. This mandate in Tanzania is enshrined in the national policy and plans for rural and urban development (Local Government Act No.8 sect. 54) which further extends the social and economic development of its area of jurisdiction. Despite the well-grounded intent of the central government, literature review unearths the following challenges on participation in bottom up planning process.

Mohammad (2010) reveals that, because of bureaucratic preponderance and distrust by the successive governments to the people, people's participation in a large scale in local 
development process remained beyond the reach of the ordinary people. Problems were associated with the local leaders who were poorly educated and lacked requisite competence. Such leaders could not effectively involve people in decision making (Babirye, 2009). As the remedy, critics maintain that unless programmes focusing on local communities are planned at a pace and in a manner consistent with local realities and capabilities, the ideology of popular participation can be counterproductive. The focus should be on the people's skills, knowledge, and motivation that can promote personal efficiency and effectiveness in the process of bottom up planning approach (Tommasoli, 2005).

Lack of all key types of resources at the local government authorities is paramount to inefficiency and ineffective bottom up participation. Planning involves substantial time spent in consultations, discussions in meetings, and actual movement to project sites in Sub-counties and lower local councils. This requires considerable allocation of resources which in most cases are limited (Conyers, 1991). Lack of resources, that seriously hinder district team/planning committees such as lack of human resources adversely curtails planning and implementation of meaningful development activities in the respective districts.

The bottom up approach that enhances local community participation in pertinent decisions emanates in top-down decision. The to-down decision advocates a bottom-up local community approach based on the anticipations, thoughts, schemes and programmes of local communities. Even though, some findings revealed that there were main five (5) issues facing participation in bottom up planning process as follows (Fjeldstad et al.,2010:5): first, delays were experienced in receiving guidelines and budget ceilings from the central government; secondly, needs and activities in local plans were not effectively rationalized /prioritised by communities, and tended rather to be "lists of wishes"; thirdly, central government priorities determined community decisions; fourthly, interaction between council staff and communities was limited; and fifthly, regional and central government bureaucrats ultimately held decision-making power over local plans.

\section{Research Methods}

In order to address the aim objective of this study data were randomly collected from four selected Wards of Korogwe Town Council. The sample comprised of 329 respondents. These respondents were sampled using purposive, simple, and convenient random sampling procedures. Data were collected through interviews, focus group discussions (FGDs), and observations (Creswell, 2007). We reviewed articles in journals, government documents, books, and website based materials on community participation. Data were analysed qualitatively and descriptive statistics were displayed in frequencies and figures. Cases were developed from interviews and FGDs.

\section{Results and Discussions}

The study portrayed several findings on the local community participation in the planning process. The key findings (fig.1) indicated that there were unmotivated and untrained council officials; inadequate fund; lack of Council mechanisms to dealing with participation; inflexible, irresponsible leaders, and the shortage of staff members. Below we present each of 
the results in detail.

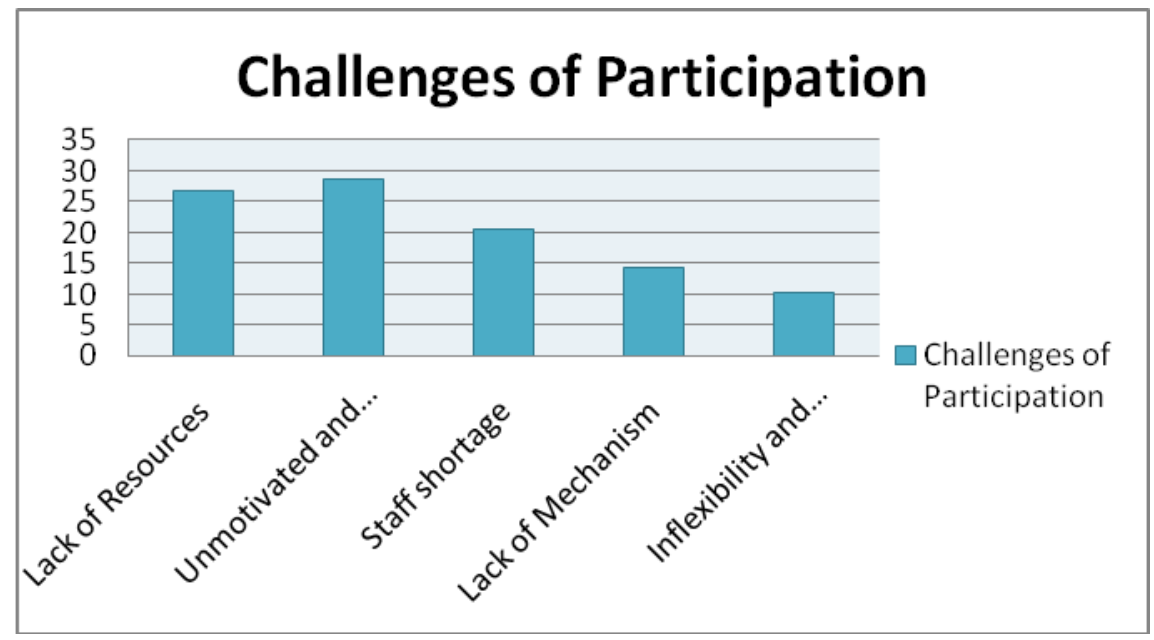

Figure 2. Challenges of Citizenry Participation

Source: Authors, 2018

\subsection{Unmotivated and Untrained Council Officials and Community Members}

It was found that those involved in preparing strategic plans were not motivated as one of the respondents asserted:

"...we have been preparing the proposed council strategic plan and budget for the year 2014/2015 for a month now, but we were given seven days extra duty allowances only. Every day we work up to 20:00 hours and no one cares".

Revealing additional dissatisfaction, one of the aggrieved respondents from WDC argued:

"...in total we are not more than thirty here, we set priorities to serve all people, nearly 23,000 in this ward, yet we do not get even some few money just to encourage us to continue working".

Taking part in the development project like this requires mobilization of people to support such initiatives. Motivation is not just an approach towards bring people together but also to make them feel that the project is their right from the inception of the idea. Interestingly Norman and Massoi (2010;2009)'s studies indicate that just like Korogwe Town Council, their findings at Kizota in Dodoma region revealed that unmotivated people could not fully participate in supporting the local community based projects. Their findings further showed that the council did not motivate community members such MEO's/ WEO's, members of the Ward Development Committee (WDC) to take part in implementation of the ward/Mtaa projects. However, the council provided council officials with food, drinks, and extra duty allowance to facilitate planning process.

While motivation is useful, it is harmful if it is misused because people may attend meetings just for the sake of drinks, food, and money. Instead of being committed to their own local development, full attendance may not be translated into long support of the project because 
they miss the link of their involvement and the long lasting of the projects (Babirye, 2009). Among other things, this may be due to lack of aggressive campaign to mobilize the people to participate in local community planning; how to get involved, and why it is important that they become part and parcel of planning process especially from the village level. However, critics do not see the significance of local community to take part in planning processes because they believe that planning is not for the local community members as they slow down the process hence it should be exclusively for the experts (Parker, 2003). Norman and Massoi (2009)'s findings support Parker's argument as they reveal that illiteracy amongst community members in budgeting rendered community planning inefficient. In addition, lacking the required technical knowhow, local community might not be committed to most of projects because it is very hard to conscientise community members (Thwala, 2009).

\subsection{Lack of Resources}

It was revealed that 26.5 percent of respondents indicated that resources were not enough to facilitate citizens at the grassroots level to provide inputs in decision making process. In particular, funds for buying fuel, hiring vehicles for transport to the local areas, paying allowances, and other activities such as facilitation costs were inadequate or not available when needed. Commenting on availability of capital one of the respondents had this to say:

"I do not know why the Council is not allocating sufficient financial resources to ensure proper participation of community members ... many local community members did not take part as the results a few people participated. Hence, it is the ideas of such few people and the leaders which form the planning processes. I cannot attend all meetings without allowances".

Ali (2013) also adds that, lack of resources to implement community identified projects has also led to low participation by the local people. Whenever planning meetings are called community members perceive that they waste time because meetings do not yield tangible results. The transition from the decisions arrived at the meeting to effective implementation, among other factors, depends on the financial capacity of the local authority. Kilewo and Frumence (2015)'s show that lack of financial resources may negatively affect efficient functioning of the meetings and developing and implementation of the decisions. Thus, creating unfavourable decisions that infringe on the people's rights and even more detrimental to the goal of the decentralization which underlines the importance of empowering the communities at the lower level by engaging everyone in the decision-making process (Babirye, 2009). However, lack of adequate budget allocation has been a stabling block to facilitate community involvement into planning (Murziki, 2015).

\subsection{Lack of Council Mechanism(s) to Dealing with Participation}

About fourteen percent of respondents believed that the KTC has no proper mechanisms, specifically for local community members to participate in bottom up planning process. There was no any setting framework like database for planning which was known to local community. There were no good communication and no supervision in planning process from the administration. Portraying the picture on this phenomenon, one of the WDC members of 
Old Korogwe had this to comment:

“...during planning process there was no provision of written feedback from KTC to ward level. Similarly, there was poor communication from the ward to Mtaa to inform them of the development priorities".

Efficient and effective communication is one of the best mechanisms for involving people into planning activities. It is very important to keep the citizens abreast with important information so that they can be ready to effectively participate in any event that affect their political, social, and economical lives. For effective local community participation in the planning process members must be aware of the process in order to own it (Mollel, 2010). It is very important the local community members to gain knowledge on issue pertaining to planning. However, findings indicated that communication was too poor to facilitate members of local community to participate as one of the members of the Municipal council asserted:

"...I have never received an invitation to attend meeting (full Council) concerning planning since I held this position. They do not even mind to distribute copies of such planning to our offices to allow members peruse and know what is going on. May be they perceive that we cannot add value by providing ideas".

Poor administration of local government affairs and lack of institutional framework were observed by Babirye (2009) as the causes for participatory planning. It was obvious these two factors could not allow flow of adequate information to the local community members. Poor information sharing resulted in poor community participations as well. The consequences would be like shock-waves, they were to affect development and implementation of the planned projects since the members did not fully take part in decision making, they could not effectively be part of the subsequent stages (Kiwelo and Frumence, 2015). It is through the communication and information sharing the local community could raise their voices and share their experiences. Through effective communication the local community members could understand the content of the plan and help to share it amongst all stakeholders for positive results.

\subsection{Inflexibility and Irresponsibility Among the Council Officials and Political Leaders}

According to fig. 1 above, 10.2 percent of respondents agree that, there were inflexibility and irresponsibility amongst the Councilors, WEOs and MEOs. There were no changes to the planning process, since policies, and regulations were put into action for community to participate in all important activities, but they wanted community members to participate in the implementation of the projects. Commenting on behaviours of the council and political leaders, one of the planning officers had this to say:

"Sometimes the minutes prepared by MEO's were not relevant to what was discussed in the Mtaa plan, also councillors did not give a chance to the experts who participated in setting Ward priorities as the results what they suggested to write in series were those from their political party instead of 
community needs"

It is one of the responsibilities of the councillors and other political officials to educate the community members about the importance of the citizens to effectively take part in community development projects (Chifamba, 2013). This entails the community members to be part of decision making. However, the current results indicate the opposite as one of the WDC members asserted:

"Our leaders do not encourage or tell us about the importance of participation. They do not involve the citizens in key issues that touch the life of every person. Some members of WDC are not willing to encourage participation in their areas, because there is no feedback of previous Mtaa Plan and priorities. And others do not clarify issues to make all members understand".

Planning requires updated information which should be communicated to the members of the group concerned responsively. Local government leaders are accountable by reporting and explaining issue pertaining to decisions reached transparently. While this requires the leaders to incorporate even every member in community, it also entails them to employ the most efficient and effective ways without bleaching the available rules and regulation so that those who are affected or interested in decision should have a venue to take part (Kampen, 2009). This fosters good relations between leaders and community members. Despite the importance of good governance being the kingpin in participation in planning at the lower level, on the ground the situation was different as one of the members of WDC commented:

"To some extent things are in slow motion. Last year's planning guidelines were late. There were no written feedbacks from the Director/ WEO too. Besides the budget being inadequate, planning activities were of less priority. No money was allocated which could be used to encourage and influence local community members to participate in planning process".

Development of the local communities depends on the strong leadership which creates avenues for community members to participate in planning process. Effective participation in planning is responsive as most of the development projects become meaningful when they address community concern timely. The type of leadership is one of the ingredients for effective planning. Nevertheless, where the community members become so sensitive to their own destiny and deem their leadership as obstacle they can change their leadership (Mollel, 2010).

\subsection{Shortage of Staff}

According to fig.1 above, 20.4 percent of respondents indicated that lack of adequate staff was an obstacle towards planning. The staff was not enough at all stages of planning process, for example, at Mtaa level MEO was the secretary of the meeting and Mtaa council, also he/she works in collecting income, supervising public projects and solve community problems. It was hard for him/her to effectively encourage the community to participate in planning process, because the deadline for collecting the revenue was the same as at the Mtaa 
and ward level. At the council level, there were only two planners. These were assisted with one community development officer. The shortage of staff members at this level and its likely consequences were summed up by the HoD planning department when he said:

"My department needs five (5) employees but we are only two (2), so how can we encourage participation of local people for bottom up planning in a good manner? In most cases, community is not directly involved in planning because of the serious shortage of staff in planning department".

Inadequate of workforce at the lower level has been one of the major problems in local government authorities (Ali, 2013). Local community require assistance and guidance in many areas of planning. Planning at the grassroots level suffered from inadequate staff members who could have supported effective participation in planning (Babirye, 2009). In addition, the current study and the previous studies such as Mollel (2010) and Babirye (2009) underline that even the available inadequate staff members were not adequately trained on various issue such as participation in planning. There were a few of motivated and trained local officials like WEOs and MEOs concerning participation in bottom up planning process. The problem was partially caused by lack of funds, specifically funds for capacity building for planning process which to some extent explicate that there was low participation in bottom up planning processes. Early on it was established that local government authorities, to a large extent depended on the central government for more than $90 \%$ financially and priorities were highly influenced by the top down approach (REPOA, 2008). At the KTC, for instance, from its establishment in 2004 to 2014 there was no any provision of training concerning participation in bottom up planning.

Most of challenges facing KMC resulted from a combination of factors, for instance, unmotivated and untrained staff as figure-1 indicates above, effected services offered, jeopardised efficiency and effectiveness and hence undermined overall productivity (Abbass, 2012). In the same vein, inadequate and untimely fund allocation has undermined capacity building. Inflexible and irresponsible leaders with low vision and inadequate leadership skills did not contribute towards enhancing community participation in bottom up planning.

\section{Remedies for Improving Participation in Planning Processes}

In connection to results we presented above, hereunder we present different ways to improve participation in bottom up planning.

\subsection{Motivation}

Findings indicate that 30 percent of the respondents believed that motivating the council officials and employees could improve the performance of the available employees. Motivations have a positive influence to a council official's active participation. While motivations satisfy the needs of individuals and groups, it also encourages job satisfactions (Camand, 2016). Members who attend meetings such as annual planning meetings should also be motivated in various ways. This is in line with the comments of one of the members of Old Korogwe WDC who asserted that: 
"Most of council officials and political leaders should be motivated if we want to set ward priorities. Once the normal sessions are over, they tell the WEOs, to complete the task. However, if the council wants a good work, it should find ways to make council members work diligently. We can spend more time and do it in the best way".

The KTC can employ different ways to satisfy the council members and other stakeholders in planning processes. The KTC should employ very carefully intrinsic and extrinsic types of motivations towards improving bottom up planning process. The availability of funds for various activities and use of money alone to motivate people cannot be effective. The process should be designed in such a way that it encourages more people to participate fully. Financial incentives have never been effective as stand alone because the needs and wants of human beings are not uniform to all people and at all times. Some people get motivated in events from which they participate and gain sense of recognition for accomplishment (Egberi, 2015). Most of the local community projects have been successfully implemented through voluntary initiatives too (Davey, 2012). Therefore, this suggests that effective participation in planning process at the local level should be organised in a way that intrinsically encourage community members to participate fully.

\subsection{Accept Changes}

About 50 percent of the respondents agreed that changes were inevitable among the council officials and leaders. KTC officials should accept changes in their performance by being flexible and responsible. They should change their mindset too. It was high time they start believing that, there was no proper planning for sustainable development without participation of local community members through bottom up planning process as one of the local community members rightly commended:

“...serious changes are needed from political leaders and council officials to encourage participation in planning at the lower level. In the nearest future no member of the community will participate in implementation, because they wonder why they do not participate in planning but only in at the implementation phase. So, it is only changes of the mindset of leaders that will ensure the effective participation of the community".

For effective process, all stakeholders at the local level must agree on the priorities and whatever changes are to be made (Ali, 2013). At all levels of decision making and implementation consideration of the needs and wants of people should be focal point especially during the annual district project planning and midterm reviews (Mosha, 2007). This is not only a way to empower the citizens at the lower level, but also to discourage traditional top-down management of community projects. If changes were to be realised, the village, or in this case the township plans would be reflected in the council plan as Mollel (2010:55) suggests:

"To assess whether or not local preferences are taken into account, one could compare the council plans with the village plans. If the council plans reflect 
development preferences contained in the village plan, there is evidence that these preferences are really taken into account. If there is no trace of these wishes, it is safe to assume that those requests are being ignored".

Effective planning can be that one which is not only involving key stakeholders, but more importantly one which accommodates the needs and wants of the lower levels. In addition, the content of plans must be understood by the community members for effective implementation and ownership of the project (Davey, 2012; Mollel, 2010). To accept changes entails that, the KTC must have the ideas and wishes of the community members well articulated in all plans and mechanisms to make people be part of planning process.

\subsection{Provision of Training Concerning Participation}

It was established that 15.7 percent of the respondents agreed that there was a need to improve local people participation in planning through either on-job training or off-job training. Increasing skills, knowledge, and changing of attitudes of the local officials will improve participation in planning at the local level. It was identified that, some people did not even know that planning process of the council starts from Mtaa level. The remedy could be as the Chairman of the Council noted:

"Training on participation is important to all levels of planning. However training is crucial, it must be specific. For instance, training should cover principles, guidelines, resource allocation criteria, operation key principles, project planning, and implementation of project to different groups of the local community based on such things as level of education and commitment towards community development."

Training aims at making the persons acquire knowledge, skills, experience and change attitude towards a desired orientation. However, issues pertaining to planning for the development of the community, require specific skills and knowledge which the government officials, community leaders and the general public must possess. However, the same knowledge should be presented to the local community members in a simplified way so that they can grasp the general ideas from which they can effectively participate in any community base project. Most of the local community members may not be conversant with complex issues such as budget evaluation and project assessment, but for instance, being aware of the budgeting basics and project evaluation can enable them to participate more effectively. They can even evaluate the projects in terms of output and even outcome and hold their leaders accountable.

\subsection{Adequate Funds}

One of the requirements for implementing planning at the lower level was lack of funds for planning. Resources are always scarce, but decisions towards acquisition need bold decisions on the sources of revenues. The KTC must widen revenue base and collect enough revenues. Having enough funds, KTC will complement costs which the central government funds do not cover. One of such areas in which KTC can use the collected revenue is to improve their own staff and empower the Council to make decisions on when and where her money should 
be used (Kimario, 2014). The KTC can use collected fund from own sources for improving staff and or hire temporarily human labour. More strategies to secure funds for capacity building in the areas of local community participation in planning involve securing permanent flow of fund for participation in planning processes every year as the WEO remarked:

"The council should delegate power to the Ward and Mtaa Executive Officers in enforcing rules and regulations pertaining to collection of levy. Money for supporting community participation can be mobilised from these levels. Every ward and Mtaa can provide a budget for planning process. This will enable wards and Mtaa to generated fund for empowering local community for planning participations".

\subsection{Participation Planning Council Policy}

In order to make participation of the local community effective, the KTC must formulate an inclusive policy for participation in planning processes. There cannot be rules and regulations that make it mandatory for the leaders at the local level to see that the ideas and wills of the community members become integral part of the planning process without a policy. The policy will make it possible not only just to involve community members in planning, but also to enable KTC assist the community leaders and people's representatives to build capacity on identifying local community needs and wants. People with increased skills and knowledge in planning can participate more efficiently and effectively. However, in order to make effective policy, KTC must conduct an inquiry by consulting officials and non-officials on how to improve participation in planning processes. Commenting on the policy matter, one of the officials from the planning departments proclaimed:

"There should be a council policy for participation in planning matters. The policy will bring together those who work in Ward and Mtaa levels to share information and experiences, build support network, and initiate policy dialogue. This will allow the community to present a common voice for our council on policy and management issues".

\section{Conclusion and Recommendations}

Drawing from the results and discussions, the evidences show that there is no effective participation of the local people in planning process. As the result, it was very difficult to implement the project at the KTC. The KTC could improve the situation by appealing to those who participate in planning process through both extrinsic and intrinsic motivation while continues to train local community members and employ more community planning staffs. The KTC can achieve all this by expanding its revenues base in order to get more funds for training local community member for planning activities and employ more planning staffs. All this will bring closer the rest of the community members for improving participation in planning process. Regarding further studies, we recommend studies to employ quantitative or mixed method approaches in order to understand the extent each factor identified impedes bottom up planning process at the local level. 


\section{Reference}

Abbass, I. M. (2012). Motivation and Local Government Employees in Nigeria. European Scientific Journal, 8(18). [Online]. Available https://eujournal.org (January 7, 2017)

Abdi, A. A. H. (2013). Determinants of Community Participation in the Implementation of Development Projects: A Case of Garissa Sewerage Project. [Online] Available: http://erepository.uonbi.ac.ke (August 20, 2017).

Akortor, A. M. S. (n.d).The Quest for Community Participation in Decision Making Process in Büyükkonuk (North Cyprus). Msc. Dissertation. Research, Eastern Mediterranean University, Gazimağusa, Institute of Graduate Studies

Ali, H. A. (2013). Determinant of commuinty Particiapation in the Implementation of Development Project:A Case of Garissa Sewerage Project. Nairobi: University of Nairobi.

Babirye, O. M. (2009). Challenges of Popular Participation in the Planning Process of Local Governments: A Case Study of Nsangi Sub-County Local Government in Wakiso District (1998-2003).Master's dissertation. Kampala: Makerere University. http://hdl.handle.net/10570/2367

Baker, J.,Wallevik, H., Obama, J., \& Sola, N. (2002). The Local Government Reform Process in Tanzania:Towards a greater interdependency between localgovernment and civil society at the local level? Kristiansand: Agderforskning.

Braathen, E., Chaligha, A., \& Fjeldstad, O. (2005). Local governance, Finances and Service Delivery in Tanzania. A Summary of Findings from Six Councils Joint Report 2005 NIBR/CMI/REPOA. Dar es Salaam: REPOA. https://doi.org/10.7577/nibr/samarbeidsrapport/2005/1

Chand, S. (2016, January 1). YourArticles Library . [online] Available: http://www.yourarticlelibrary.com (June 30, 2017).

Chifamba, E. (2013).Confronting the Challenges and Barriers to Community Participation in Rural Development Initiatives in Duhera District, Ward 12 Zimbabwe, International Journal of Current Research and Academic Review, 1(2), 21-19.

Cooksey, A., \& Kikula, I. (2005). When Bottom-Up Meets Top-Down: The Limits of Local Particiapation in Local Government Planning in Tanzania. Dar es Salaam: Mkuki na Nyota Publishers.

Creswell, J. W. (2003). Research Design: Qualitative, Quantitative, and Mixed Methods Approaches. Thousand Oaks: Sage Publications.

Creswell, W. J. (2007). Qualitative Inquiry and Research Design:Choosing Among Five Approaches. 2nd Ed. London: SAGE Publications.

Davey, K. (2012). Local Government in Critical Times: Policies for Crisis, Recovery and a Sustainable Future. Strasbourg: Council of Europe. 


\section{Macrothink}

Journal of Public Administration and Governance ISSN 2161-7104 2018, Vol. 8, No. 1

Egberi, E. (2015). Motivation and Employees' Productivity in Local Government System in Nigeria: An Evaluation. Journal for Studies in Management and Planning, 2(3), 148-162.

Fjeldstad, O. H. (2010). Fiscal Decentralization in Tanzania: For Better or For Worse? Bergen: Chr. Michelsen Institute Development Studies and Human Rights.

Fjeldstad, O. H., Katera, L., \& Ngalewa, E. (2010). Planning in Local Government Authorities in Tanzania: Bottom-up. REPOA Brief No. 18, January.

Hillary, A. (2010). Analysisng of Effectivveness of Particiapation of Communities in Formulating and Managing Project. Unpublished Disseration. MPA Mzumbe University.

Kampen, K. J. (2009). Good Governance at the Local Level: Toward A Global Village or A City Republic? Economic and Environmental Studies, 9(1) (12/2009).11-30.

Khwaja, A. I. (2004, April-May). Is Increasing Community Participation Always a Good Thing? Journal of the European Economic Association, 2(2-3).427-436.

Kilewo, G. M., \& Frumence, G. (2015). Factors that Hinder Community Participation in Developing and Implementing Comprehensive Council Health Plans in Manyoni District, Tanzania. Global Health Action, 8(1), 1-10. https://doi.org/10.3402/gha.v8.26461

Kimario, P. (2014). Challenges Faced By Local Government Authorities (LGAS) In Implementing Strategies to Enhance Revenues: Case of Dar es Salaam Municipal Councils. [Online] Available: http://repository.out.ac.tz (January 7, 2017).

Krull, S. (2014). Rethinking Organisational Approach to Project Management, Long Term Infrastructure Planning and Capital Works Delivery. Wyndham: Municipal Engineering Foundation Victoria.

Mallya, E. T. (2015). A Critical Look at Tanzania's Development Vision 2025. Strategic Long Term Planning and Policy Management. [Online]Available: https://scholar.google.com/scholar (September, 2017).

Manghenzi, A. (1976). Class, elite, and community in African development. Uppsala: Scandinavian Institute of African Studies.

Marzuki, A. (2015). Challenges in the Public Participation and the Decision Making Process. Sociologija i proctor, 201(1), 21-39.

Matovu, G. (2006). Capacity Building for Participatory Planning and Budgeting in Africa: Initiatives and Strategic Perspectives: Paper presented at the Pan African Conference of Ministers of Local Government held in Maseru, Kingdom of Lesotho, from August 30th to September 1st, 2006

Mayo, M. (1994) Community Participation, Community Development and Non-Formal Education. The informal education archives. [Online]Available: http://infed.org (August, 2017). 
Michels, A., \& De Graaf, L. (2010).Examining Citizen Participation: Local Participatory Policy Making and Democracy. Local Government Studies, 36(4), 477-491. https://doi.org/10.1080/03003930.2010.494101

Mohammad, N. S. (2010). People's Participation in Development Projects at Grass-Root Level: A Case Study of Alampur and Jagannathpur Union Parishad. [Online] Available: http://www.mppg-nsu.org (August, 2017).

Mollel, A. H. (2010). Participation for Local Development the Reality of Decentralization in Tanzania. African Studies Collection, vol. 29. Leiden: African Studies Centre.

Mosha, A. C. (2007). The Experience of Sub-regional Planning in Botswana: Achievements and Challaenges. Regional Development Dialogues, 28(1), 93-110.

Norman, S. A., \& Massoi, L. (2009). Decentralisation by devolution in Tanzania: Reflections on community involvement in the planning process in Kizota Ward in Dodoma. Journal of Public Administration and Policy Research, 1(7), 133-140.

Norman, S. A., \& Massoi, L. (2010). Decentralisation by devolution: Reflections on community involvement in planning process in Tanzania. Educational Research and Reviews, 5(6), 314-322.

Nour, M. A. (2011).Challenges and Advantages of Community Participation as an Approach for Sustainable Urban Development in Egypt, Journal of sustainable development, 4(1), 79-91. https://doi.org/10.5539/jsd.v4n1p79

Parker, B. (2003). Planning Analysis: The Theory of Citizen Participation. [online] available: http://pages.uoregon.edu (January, 2017).

REPOA. (2006). Participatory Approaches to Local Government Planning in Tanzania:The Limits to Local Particiapation. Dar es Salaam: REPOA.

Sounders, M., Lewis, P., \& Thornhill, A. (2009). Research Methods for Business Students. 5thEd. London: Pearson Education Limited.

Tamale, L., \& Kitamirike, E. (2015). Making Decentralization Work for the People of Uganda: Policy Issues Ahead of the 2016 Elections. The Situation Room Uganda Debate Briefing Papers, No 2 of 2015. GLISS, UYONET, NTV, Kampala

The United Republic of Tanzania (1982b). The Local Government Finances Act, 1982. Dar es Salaam:URT

The United Republic of Tanzania. (1982a).The Local Government (District Authorities) Act, 1982. Dar es Salaam: URT

The United Republic of Tanzania. (1999). Tanzania Development Vision 2025. Dodoma: Planning Commission, Prime Minister's Office, Regional Administration and Local Government (PMORALG). 


\section{Macrothink}

Journal of Public Administration and Governance ISSN 2161-7104 2018, Vol. 8, No. 1

The United Republic of Tanzania. (2004). Opportunities and Obstacles to Development (O\& OD) Manual. Dodoma: PMORALG.

The World Bank. (2004a). Local Pathways to Global Development: Marking Five Years of the World Bank. Indigenous Knowledge for Development Program. New York: Knowledge and Learning Group.

The World Bank. (2004b). World Development Report: Making Services Work for Poor People. Washington DC: The World Bank.

Thwala, W. D. (2009). Experiences and Challenges of Community Participation in Urban Renewal Projects:The Case of Johannesburg, South Africa. Journal of Construction in Developing Countries, 14(2), 37-54.

Tidemand, P., \& Msani, J. (2010). The Impact of Local government Reforms in Tanzania 1998-2008. Dar es Salaam: REPOA.

Tommasoli, M. (2005). Representative Democracy and Capacity Development for Responsible Politics: Sixth Global Forum on Reinventing Government Seoul, Republic of Korea 24-27 May 2005. Stockholm: IDEA.

\section{Copyright Disclaimer}

Copyright for this article is retained by the author(s), with first publication rights granted to the journal.

This is an open-access article distributed under the terms and conditions of the Creative Commons Attribution license (http://creativecommons.org/licenses/by/4.0/). 